\title{
Competency Development of Social Science Teacher Candidate in Supporting Education for Sustainable Development
}

\author{
Fredy Hermanto ${ }^{1}$, Noviani Achmad Putri ${ }^{2}$, Aisyah Nur Sayidatun Nisa ${ }^{3}$, Asep Ginanjar ${ }^{4}$ \\ \{fredy@mail.unnes.ac.id ${ }^{1}$, noviani.ips@mail.unnes.ac.id², aisyah8816@mail.unnes.ac.id ${ }^{3}$, \\ asep.ginanjar@mail.unnes.ac.id $\left.{ }^{4}\right\}$ \\ ${ }^{1,2,3,4}$ Universitas Negeri Semarang, Indonesia
}

\begin{abstract}
Inclusive education and equivalent quality, and support lifelong learning opportunities for all is one of the objectives that want to be achieved in sustainable develpoment goals. Social change in this modern era almost struck all aspects of life, including education. Overcoming rapid changes and greater and complex challenges, there is no way for education institutions except for ways to increase the competitiveness of graduates as well as academic products and other services, among others achieved Improving the quality of education. In carrying out its duties as an institution that produces prospective teachers, the social education Department is required to improve its adaptive quality and relevant to the needs of the school environment, so that graduates are produced have knowledge and expertise so that they can participate actively in the field of continuing education. The things that have been done to make this happen: (1) Develop a curriculum that provides students with the opportunity to develop values, skills and knowledge so that they can contribute to sustainable development, (2) Provide insight to students about the world of education through innovative, adaptive, contextual learning through learning, public lectures, and training programs, (3) Develop innovations, technology and methods in the learning process, (4) Cooperate with educational stakeholders by implemtation of devotion to the community. The methods in this study use qualitative research methods, with the retrieval of primary and secondary data sources. Data collection tools and techniques include interviews, observation documentation. The validity technique in this study by using data triangulation.
\end{abstract}

Keywords: Teacher, Education for Sustainable Development.

\section{Introduction}

Globalization has had an influence in various fields of life. In the current era of globalization, every citizen is required to have a number of skills needed in life not only as citizens in his country, but also as citizens of the world. Some of the skills needed in the globalization era include: [1] 1) critical thinking and problem solving, 2) collaboration across networks and leading influence, 3) agility and adaptability, 4) initiative and entrepreneurialism, 5) effective oral and written communication , 6) accessing and analyzing information, and 7) curiosity and imagination (Wagner, 2008). In line with Wagner's thinking, Metiri Group (2009) [2] suggested several skills that needed to be mastered, including: 1) digital age literacy, which included (a) basic, scientific, and technological literacy, (b) visual and information literacy, and (c) cultural literacy and global awareness; 2) inventive- 
intellectual capital thinking, which includes (a) adaptability / managing complexity and independence (self-direction), (b) curiosity, creativity and courage to take risks, (c) thinking in a higher and reasoning order; 3 ) interactive communication - social and personal skills, which include (a) working in groups, and working together (collaboration), (b) personal (personal), and social responsibility, (c) interactive communication; 4) quality and up-to-date results, which include (a) prioritizing, planning and managing results, (b) using real-world tools effectively, (c) high-quality results with application to the real world.

The influence of globalization that must be anticipated immediately is the implementation of an integrated economic zone known as the ASEAN Economic Community (AEC). With the enactment of the AEC, of course this can be an opportunity or even a problem for the Indonesian nation, depending on the readiness of human resources owned by Indonesia, currently the quantity of the Indonesian population is very large, but in quality there are still many problems that must be solved by the Indonesian people.

Based on the results of the analysis of the [3] Ministry of Education in 2016 that the number of school principals and teachers who are eligible to teach or have S1 or D4 diplomas is $84.82 \%$ means that there are still $15.18 \%$ of school principals and teachers who are unfit to teach, HR performance is based on 5 indicators of education (diplomas, according to sex, according to employment status, according to civil servant status, and according to age) indicate that the performance of education and training is in the less category with a value of 77.69 [3] (Pusat Data Dan Statistik Pendidikan Dan Kebudayaan, 2016). From these data, it can be seen that Indonesia's readiness in dealing with AEC in terms of the quality of Human Resources still requires an effort to increase competitiveness at the Southeast Asian level.

A Number of skills that are required to be possessed by all citizens in the era of globalization certainly have an influence the education sector. The education sector must be able to respond and anticipate developments of labor market liberalization and the development of science-based society. Quality human resources are also a demand and a necessity to be able to face very tight competition in fighting for jobs that are increasingly narrow due to the enactment of the AEC. To produce quality human resources, able to compete with all nations in the world, all components of society, especially the education sector, are demanded to play a role in improving the quality of education and learning.

Universitas Negeri Semarang (UNNES) as an ex-LPTK college consisting of several study programs and departments was given the task by the Government to organize teacher procurement programs in early childhood education in formal education, basic education, and/or secondary education, as well as to organize and develop education and non-education have a strategic role to produce teachers and prospective teachers who meet the standards and professionals. One of them is the existence of Prodi Pendidikan IPS has the role and responsibility to develop the trustee, especially to print social studies teacher candidates who meet the standards and professionals.

Prodi Pendidikan IPS has a vision to become a superior study program in the field of Social Sciences Education that cares about the environment, based on Indonesian social and cultural values and has an international reputation. In addition, one of the missions of Education in Social Sciences is to carry out a thematic integrative social science education and quality and based on ethics and morals to produce graduates with character and professionalism. Through the Vision and Mission, Prodi Pendidikan IPS has a program on how to prepare social studies teachers who are not only professionals but also have a passion for lifelong learning and care for the environment. Create professional teachers is an effort to create human resources that have global competitiveness. Create teachers who have the spirit of lifelong learning is an effort to create teachers who continuously improve their abilities and 
self-quality so that their knowledge will always be in accordance with the demands of the times. Create teachers who care about the environment is an effort to create teachers who have an awareness of sustainable development which is self-awareness of their responsibilities as human beings who are part of nature and live in harmony with nature. By trying to create professional teachers who have the spirit of lifelong learning and care for the environment, it is expected that they will be able to improve the quality of human resources which can be a solution to various problems both now and in the future.

Thus it is necessary to develop the competencies of social studies teacher candidates who can support education for sustainable development, so that later Social Studies teacher candidates in carrying out their roles in the world of education are not only focused on cognitive domains, but also can improve the quality of human resources that can compete and have concern for the environment, so that it can support sustainable development. In this article, the author will examine how Prodi Pendidikan IPS can develop the competency of social studies teacher candidates in supporting education for sustainable development.

\section{Method and Research Design}

This study uses a qualitative method. In qualitative research efforts are made to interpret or interpret an event, interaction, or human behavior at a certain time with the perspective of the researcher himself and carried out in natural settings. The research was conducted at the Social Sciences education study program and the FIS UNNES with the research subjects being FIS and Prodi Pendidikan IPS leader, as well as lecturers and students of Prodi Pendidikan IPS. With the focus of research on developing the competencies of prospective Social Sciences Teachers in supporting education for sustainable development. The data used are mostly qualitative data with primary and secondary data sources. The data was obtained by interview and interview techniques, observation, documentation and field notes. The validity of the data in the study uses data triangulation techniques. Triangulation of the data used are (1) Triangulation of data done by checking the data obtained from various sources including the Dean, Vice Deans, Head of Social Education, Lecturers, Students, Alumni, and School partners. Retrieval of data taken at different timesin the morning and evening. Data collection is also carried out in different places on Campus and School. (2) Triangulation of researchers, done by inviting several other researchers who have similar research in a Focus Group Discussion related to increasing the competence of social studies teachers. (3) Triangulation methodology, done by checking the results of observations with the results of interviews, such as the results of interviews related to the completeness of curriculum checked with the results of observations that indicate the lack of curriculum documents. (4) theoretical triangulation, done by checking the results of data in the field with the theory used in this study, one of the theories according to Kunandar "Professional teachers are teachers who have the competencies required to carry out educational and teaching tasks. This competency includes knowledge, attitudes and professional skills, both of a personal, social and academic. Qualitative data analysis in Miles that the author uses consists of three activity lines, namely data reduction, data presentation and conclusion drawing.

\section{Results and Discussion}

Each country should place higher education institutions in achieving sustainable development through the knowledge and expertise of their graduates in a tangible form and through their strategies and performance (Siddiqui, et al., 2006) [4]. Sustainable education 
aims to ensure that everyone has a quality education opportunity, so that learners can learn about values, attitudes and lifestyles that support a sustainable future and to realize a positive community perspective (Ali, 2006) [5] Activities regarding sustainable development are based on a comprehensive approach to the three main pillars, namely the environment, society and the economy, and refer to the cultural dimension. For this reason, in the implementation of learning in higher education, it is necessary to carry out development as well as comprehensive perspective changes so that the people involved in it carry out sustainable education. In carrying out its mandate as an institution for printing teacher candidates, Social Sciences Education Study Program is required to improve its quality that is adaptive and relevant to the needs of the school environment, so that graduates produced have the knowledge and expertise so that they can actively participate in the sustainable education . Things that have been done to make this happen include:

\subsection{Develop a curriculum that provides opportunities for students to develop values, expertise and knowledge so they can contribute to sustainable development}

Integration of education for sustainable develoment into the curriculum in learning is determined by the leadership leadership of related officials in universities in this case starting from the central level, faculty, to study programs. The leadership held by UNNES as a college, the Faculty of Social Sciences to the Social Sciences education study program took place dynamically and supported the academic development of lecturers and students. This brings a paradigm shift in the learning process to students, so the learning approach becomes as expressed by Flores 2011 [6] which is characterized by contextual, innovative, and constructive, focused, comprehensive, integrative, process-oriented, critical thinking, systemic, and the connectivity leads to goals and learning aimed at building student ethics, as well as learning to develop cognitive, affective and skills in an integrated manner.

At the beginning of its establishment in 2014 IPS education used a curriculum developed in 2012. One year later the IPS education study program used the 2015 curriculum, the next two years in curriculum changes were made again using the KKNI curriculum. KKNI can be interpreted as a statement of the quality of Indonesian human resources whose qualifications are stated in the learning outcome. Every tertiary education must have a curriculum that ensures its graduates have qualifications that are equivalent to the qualifications agreed upon in the KKNI. Therefore, every university has an obligation to facilitate its study program to carry out curriculum restructuring. The curriculum change is a form of adaptation carried out by the study program considering the rapid demands and advances in technology. The use of the KKNI curriculum requires students of Social Sciences education study programs to fulfill the criteria in terms of attitude, expertise in their work fields as prospective teachers, knowledge, and managerial abilities and responsibilities. The use of the KKNI curriculum requires the IPS education study program to prepare a profile of graduates, so that the graduates produced will have the quality because in the profile of the graduates it contains the competency standards of graduates and learning outcomes. The potential possessed by students will be honed when using this KKNI curriculum so that they will have extensive insight, have skills and can contribute to sustainable development.

In particular the Social Studies Education Study Program develops a curriculum so that students have and understand the four competencies that must be possessed by the teacher. These competencies are professional competence, pedagogic competence, social competence, and personality competence. To master the professional competencies of social studies students, Social Sciences Education Study Program provides students with an understanding of social studies teaching materials in schools and mastery of social studies curriculum applied 
in schools. The application is prepared by the Social Sciences Education Study Program in various scientific subjects that support students to master the social studies education material that applies at school. Pedagogic competencies are given so that students understand how to design, implement and evaluate meaningful social studies learning. Social Studies Education Study Program in the KKNI curriculum is used to provide teaching and learning strategy planning courses, learning evaluation, micro teaching so that students can have a basis for developing such pedagogical competencies.

Social studies education programs in the KKNI curriculum provide students with character education courses. Giving these courses is expected to shape the character of students so that students have personality competencies and foster positive thinking skills in living in a society. In order to master the social competencies possessed by students, Social Sciences education study programs provide students with courses in Indonesian society, human and environmental studies so that students are expected to adapt to the environment and society wherever he works. The course will also sharpen the sensitivity of students to environmental conditions in real life.

\subsection{Providing understanding to students about the world of education through innovative, adaptive, contextual learning, public lectures, and training programs}

Social Studies Education Study Program develops the learning process for students through innovative, adaptive, and contextual learning in accordance with the demands of the world of work. The development that has been carried out includes conducting learning with the blended learning model in lectures. This model in its implementation performs a combination of face-to-face learning in the classroom with an online system. The combination is expected to provide insight to students that current learning has taken advantage of technological developments, so students also have to be able to adapt and master technology so that they can use it in the learning process in the classroom.

Social studies education study programs also conduct public lectures to broaden students' knowledge about developments in the world of social studies and learning in particular. The general lecture material given is not only about social studies learning, but also about other things that support students to understand the world of education. Some public lectures that have been conducted by the Social Sciences education study program invite leaders who are experts in their fields, with several themes, among others, the community of industrial revolution era 4.0, social science education in development, peace education. The existence of the public lecture program is expected to broaden students' knowledge about the world of social studies in particular so that they can prepare themselves before undergoing their profession to become teachers and change the mindset of students so that they can develop social studies learning on an ongoing basis.

The training program conducted by the Social Sciences Education Study Program is based on the profile of graduates who will be owned by students, namely to become prospective educators. Therefore the training programs carried out by the Social Sciences education study program are focused on training in managing learning. This training was conducted in the 6th semester before students also practiced teaching in the field. Training is given at the end of the semester so students can use the theories that have been obtained in previous semesters. After training, students then practice field experience in designated schools. In the practice of this field experience students are given the opportunity to teach junior high school students on social studies subjects. This activity will provide meaningful experience to students regarding the problems of the teaching profession. Various problems 
must be solved by students with the guidance of lecturers and teachers at the school, so that students can find solutions to overcome these problems. This is a place for student proof of the theories that have been learned to be applied in real life in the community.

\subsection{Develop innovations, technology and methods in the learning process}

The college should change the mindset in the 4.0 industrial Revolution with more open to new science. So it can be generated breakthrough and innovation system education and learning. Colleges should be more open by means of having an open mindset and continuing to develop science. Amid the complex global challenges, the hope of Indonesian Government and society to the college is very high in providing education to the nation's successor generation to be competitive, creative, and innovative in the current disruption era. Therefore, technological developments should be followed by innovations in the learning system. Need creativity if we do not do this, we will be left behind from other countries and the most needed is creativity.

The rapid development of information technology in the era of globalization is now inevitable impact on the world of education. Global demands require the educational world to always and continuously adapt the development of technology to the efforts in improving the quality of education, especially the adjustment of the use of information and communication technology for the world of Education, Especially in the learning process.

According to H. Hamzah B. Uno and Hj. Nina Lamatenggo, $(2011,61)$ in Budiman (2017) [7], said that the trend of education in Indonesia in the future is as follows:

a. Development of open Education with distance learing mode. Then to organize an open education and long distance need to be included as a main strategy;

b. Shareng shared resource between educational institutions in a network of libraries and other education istruments (teachers, laboratories) changed the function into a source of information than just a bookshelf;

c. The use of interactive information technology devices, such as multimedia CD-ROMS in education gradually replaces the TV and video. With the development of technology and information in education, then it is possible to held distance learning by using Internet media to connect between students with lecturers, see the value of students Online, check the finances, see the lecture schedule, submit the task file given the lecturer and so on.

The development of information and communication technology has made an impact on Endidikan especially in the learning process. According to Rosenberg in G. Gunawan (2009) in Sudibyo (2011) [8], with the development of information technology and communication, there are five shifts in the learning process, namely: 1) from training to appearance, 2) from classroom to anywhere and Any time, 3) from paper to "on line " or Internet channel, 4) from physical facility to working network facility, 5) from cycle time to real time.

This change of demands that encourages institutions in particular the Social Science Education Study Program as an educational institution requires innovation and creativity in the learning process to score prospective teachers who can contribute to Support Education for sustainable development. Efforts to develop technological innovations and methods in the learning process, which has been conducted Prodi social sciences education, including:

a. Learning is carried out based on facts or evidence of the field.

Learning is done in the Social Science Education Study Program, almost everything is fact based and evidence in the field. The learning done in the classroom is based on facts and results of research in the field obtained from students, lecturers or other sources. 
Then the fact is discussed in theory based on the courses that will be studied together. For example, social pathology courses, students examine social issues in the field such as: poverty, criminality, Community Development programs, drugs etc., which then data from the field are discussed jointly in the classroom.

b. Individual learning becomes group learning.

Group learning is the main thing that is applied to the course at the Social Science Education Study Program. Group learning is carried out from delivering material using peer systems to even group-based assignments. For example, students examine the implementation of Multicultural education in schools. Then students will go to the field looking for data related to Multicultural education in various schools that have been appointed. It is aimed to not only know the knowledge in theory only, but also to know the condition in the field like what. Thus learning will be more real.

c. Theoretical learning is becoming practice oriented.

Linking between theory and practice in the field. Learning oriented to the practice of course this is a major goal for the department to print professional candidates. There are many courses that require students to practice field in the individual, such as teaching practice and group practice such as media production practices, social phenomenon study practices, practice of making maps and practices Create a learning device for Social Science Education. It aims to make Social Science Education students have the skills that suit their field.

d. Learning focuses on the knowledge toward self-regulatory that is oriented towards the issues of Education for Sustainable Development.

Learning in the Social Science Education Study Program emphasizes on Education for Sustainable Development issues. For example, human rights, gender equality, cultural diversity and cross-cultural understanding, the environment and others. The issues are very closely related to Social Science Education, where the object is a society. These issues are an ingredient in the development of materials that exist in each course. Through the skills of the Social Science Education Study Program lecturer, students are trained to be sensitive to social problems and skilled in providing solutions to the problem, to make research activities in Field.

The learning process above can be successful while supported by a good system. Social Science Education Study Program seeks to achieve good learning process using existing technology, including:

a. Provision of academic services based on online, ranging from "Sikadu", "Sitedi", "Sim PPL and KKN", "Siradi", "Sibima" etc. The system is integrated into one so as to facilitate students in taking care of various matters pertaining to their academics. The system can be accessed anywhere and anytime.

b. Implementation of online learning with blended learning system with accessible address "elena.unnes.ac.id". In this system, the lecture can be carried out not to be face-to-face but with a remote system, this is in line with the decree of the Minister of National Education No. 107/U/2001 [9] clearly opens the Corridor to organize Distance education, where e-learning can enter role plays. All materials, teaching materials and tasks related to the courses that have been taken by students in the semester are accessible to students anytime and anywhere. The material accessible to the student in the system is a learning module or video. In addition, it is not only material but the task has also been integrated in the system. Elena is very helpful in the process of learning in the present era because it uses advanced technology. 
c. The learning process is also created through the Whatsapp app. Some courses are created by WhatsApp group, in order to facilitate communication between lecturers and students. Some important and up to date information from lecturers can be directly on the share to students in order to be learned directly. It also facilitates the communication and transfer of important knowledge relating to the materials concerning the lecture. In addition to this media WhatsApp app makes it easier for group discussions. Through whatsap group can be among students can be easier to do groups discussion without having to gather

d. The use of the Telegram application also makes it easy for students to access academic information and facilitate lecturers in announcement. This integrated system makes it easy to access information that is certainly very easy in the learning process

e. Use of digital literacy. With the technology for the method of learning students will have a wider knowledge as an example of Google that has a lot of articles of journal research results, modules and Books Online can be easily accessed for free by students. Some tasks are given by the father of the internet based lecturer so that hopefully students can be well trained in the use of digital literacy. The university also provides a variety of journal links that can be accessed by students as a solution to access world-quality academic materials. Students ' work can also be gathered collected by the destination email can reduce the use of paper in accordance with the vision of the mission of the Universitas Negeri Semarang, Conservation University.

f. English language training to Social Science Education students. The English language training of Social Science Education students is not only given by the lecturers of the department, but also brought the party from the outside of Mrs. Agnes as a practitioner and teacher of English language. This training activity aims to provide foreign language skills to students so they will be ready to go to the workplace. This training also aims to prepare students to follow "PPL" among nations who have to use a minimum language of English language.

\subsection{Cooperate with the stakeholders of education by implemtation of devotion to the community}

The various efforts and future designs that have been and will be carried out by the Social Studies Education Study Program above are not enough to be carried out by only one party. But also needs support from various parties, especially stakeholders related to education or graduate users. Collaboration between holders or stakeholders is a very important thing to achieve the goals set by the Study Program. The purpose of creating qualified graduates of prospective teachers certainly needs support from all parties. Stake holders here aim to be able to provide input, criticism and support for study programs related to printing professional graduates. Stakeholders in this study include:

a. Education Authorities

The Education Office is an important party in relation to the partnership between Prodi and the policy holders. Partnering with the Education office has the aim that the Social Studies Education Study Program is aware of the development of the current education regulations. So that later the Social Sciences teacher candidate knows what policies are related to his profession.

b. Headmaster

Partnering with school principals is a very digital matter because it involves about where these future teachers will be teaching practices and also concerning graduate users. The hope is that through a partnership with the study program school, it can prepare 
graduates of the prospective teacher later in accordance with the expectations and input from the principal. That is because the principal knows the immediate needs in the field.

c. Use of graduates

Graduates from Social Sciences Education study programs are not only printed as teachers, but also can work with various parties that are still relevant to their knowledge. Social studies graduates can do work outside the field of teacher training, such as in the fields of Tourism, Advertising, Press, public consultants, Police, and even entrepreneurship. Therefore it is very important for Social Studies Education Study Program to continue to establish partnerships with various existing parties, one of which is by doing community service. Through these activities a good partnership will be established so that it can support study programs in printing qualified and efficient social studies teacher candidates.

\section{Conclusion}

The conclusion from what the writer conveyed according to the research conducted was. 1) developing a curriculum that provides opportunities for students to develop values, expertise and knowledge so that they can contribute to sustainable development, 2) provide understanding to students about the world of education through innovative, adaptive, contextual learning through learning, public lectures and training programs, 3 ) develop innovation, technology and methods in the learning process, 4) cooperate with world education stakeholders with the implementation of community service.

\section{References}

[1] Wagner. T.: The Global Achievment Gap. Basic Books, New York (2008)

[2] Metiri Group: Twenty First Century Skills (Online). Available: http//www.metiri.com (2009)

[3] Pusat Data Dan Statistik Pendidikan Dan Kebudayaan, Jakarta. (2016)

[4] Siddiqui, et al., Education for Sustainable Development, Comsats, Islamabad, (2006)

[5] Ali.M.B from Rio to Johannesburg: Achievment and Failures in Sustainable Develoment, Comsats, Islamabad. (2006)

[6] Flores, Ce dan Paul K. Teaching and learning sustainabililty in Business Scholl' dalam Final Report (2011)

[7] Budiman, Haris. The Role of Information Technology and Communication in Education. Al Tadzkiyyah: Journal of Islamic Education, Lampung, Volume 8, May 2017. (2017)

[8] Sudibyo, Lies.Role and Impact of Information Technology in the World of Education in Indonesia. Sukoharjo. 2011cation No. 107 / U / 2001. 